\title{
From New Order to Reformasi: Indonesian Subnational Politics in the Post-New Order Era ${ }^{1}$
}

\section{Leo Agustino \& Mohammad Agus Yusoff}

School of History, Politics and Strategic Studies, Faculty of Social Sciences and Humanities, Universiti Kebangsaan Malaysia (UKM), Malaysia

Email: leoagustino@yahoo.co.id

\begin{abstract}
Direct local election in Indonesia has been run since the middle of 2005. It is bringing some changes, especially in political reformation. Changed election mechanism to direct election done by the society in the region. This article seen that the changes has brought some positive impacts to the society as growing increasingly broad political participation, the legitimacy of local heads becomes higher and political party roles also become important. This changed which the author said as a form of deeper democratic process to "new democracy" in Indonesia. In addition, some weaknesses also appeared, such as the booming of money politic, weaken of regional institution and the emergence of new local elites. It leads to government as a minority in the scope of the power legislative institution which act as majority.

Kata Kunci: politik daerah, polycentrism, aktor kuat lokal, redistricting
\end{abstract}

\begin{abstract}
Abstrak
Pemilihan kepala daerah langsung di Indonesia telah dilaksanakan sejak pertengahan tahun 2005. Hal ini membawa sejumlah perubahan, terutama dalam hal reformasi politik. Mekanisme pemilihan kepala daerah diubah kepada pemilihan secara langsung oleh masyarakat di daerah. Tulisan ini melihat bahwa perubahan ini membawa beberapa dampak positif kepada masyarakat seperti tumbuhnya partisipasi politik yang semakin luas, legitimasi kepala daerah menjadi semakin tinggi dan peranan partai politik menjadi sangat penting. Perubahan inilah yang penulis sebut sebagai wujud dari proses pendalaman demokrasi bagi 'demokrasi baru' di Indonesia. Selain itu, muncul juga beberapa kelemahan, seperti tumbuh suburnya politik uang, semakin melemahnya institusi daerah dan munculnya kekuatan elit lokal. Hal ini akan mendorong tumbuhnya pemerintah minoritas dalam lingkup kekuatan lembaga legislatif yang berposisi mayoritas.
\end{abstract}

Keywords: local politics, polycentrism, local strongmen, autonomy, redistricting

\section{INTRODUCTION}

Discussions and studies on subnational politics in the Indonesia's post New Order are of an interesting subjects. This is because subnational political issues could give diametrical impacts. The situation arises due to the overlapping interests between central and district government, inter-alia the establishment and redistribution of district autonomy. Hence, the overlapping has resulted in to two major implications. It has produced negative and positive benefits to the society.
In terms of positive consequences, subnational politics contributes to the common benefits to parties that are involved. It has created a people's oriented government servants and at the same time increased public services' productivity and a better public relations services to the common people. Furthermore, infrastructure projects tend to involve public opinion on its sustainability and suitability; health services has become more efficient, if not much better in some of the local districts. Indonesia's local political conditions at the district level enjoy more 
freedom to nominate their own local representation, hence, has done away with the old practices of having leaders whose appointment and selection were decided by political elites in Jakarta. This new practice also witnesses an increasing participation, involvement and selection of women in the local political arena.

Nonetheless, subnational politics in the post-new order (Order Baru) period has also its own negative impacts. Hence the major purpose of this article is to analyze the challenges and problems of subnational politics in the post-Soeharto period. This paper argues that Indonesia's political transformation process has been marred by political opportunists at local level, who seized the changing situation to their advantage. Sometimes they are labeled as free political riders who portray themselves as reformers and use all avenues of political logic to survive in a new political environment. Although these free riders were part of manipulative actors during the New Order regime, they were quick to adapt to the new role as if they are also true reformers in the post-Soeharto period. Their manipulative political strategies then led to some interesting questions-why do these manipulative political strategies exist during the transformation period of Indonesia's politics? Has it to do with the political legacy of the New Order period?

The paper is organized into several sections. The first section would review existing literature on the Indonesia's post-Soeharto period by discussing issues on subnational politics in various parts of the archipelago. The second section analyses Indonesia's subnational politics during the New Order/Soeharto period, and finally the paper analyzes the dynamics of Indonesia's subnational politics, in terms of issues and challenges in the post-New Order period.

\section{METHODOLOGY}

\section{UNDERSTANDING CONCEPT AND THE UNIT OF ANALYSIS}

Indonesia's politics in the post-New Order is basically a reflection of societal resentment against the old style politics of authoritarian rule, which was repressive and centralized. This so-called "new politics" also witnesses the birth of polycentricism phe- nomenon-a regional collective struggle that reject old ideas of governing deemed to be undermining local identity and power.

According to Laclau \& Mouffe (1985), Escobar \& Alvares (1992), Mohan \& Stokke (2000), this phenomenon is a kind of movements or struggle that went against the idea of centralization (which for such a long time has accumulated its strength and power to weaken regional politics either in its formal and informal form). As a result, subnational economy becomes static. The situation also resulted in a strong cultural resistance (i.e. the creation of movement campaigning for local wisdom values) calling for alternative solution to the development of districts. Laclau \& Mouffe (1985), Escobar \& Alvares (1992), Mohan \& Stokke (2000) also argue that the new political culture backed by civil societies is an avenue for struggle to recreate local identity that has been denied by the earlier autocratic regime. ${ }^{2}$

Social resistance movement through civil society did succeed at the end of 1980s in Eastern Europe, especially when some of those countries collapsed due to the end of the Cold War (Diamond, 1994; Wellhoer, 2005). This shows that the role of civil society is very important in creating a new political phenomenon that expounded the idea of polycentricism. They acted as the agent for the empowerment of civil society and at the same time as a guardian of check and balance mechanism to the government's political activities.

The impact of this new politics and polycentricism has changed Indonesia's local political landscape at provincial and district levels. District autonomy, redistricting, and direct election for district head (Pikilda) are some of the examples. Nonetheless, not all changes brought about by this new politics create common benefit to the public. In India, for instancethe biggest democratic country in the world, democratization has triggered new challenges to local politics. It has in fact strengthened the caste and class politics in the society (Hansen, 1999). As a result, the dynamism of subnational politics in India has also exposed its local politics into a lucid political manipulation. 
The phenomenon also happens in Camaçari, Brazil. Camaçari's "New Political" wave encourages a new set of political values-"clientism" between economic and political interests of elites. It leads to a governing malaise of inefficiency, ineffectiveness and non-functionality. This can be seen when local district's financial independence was robbed by political and economic elites (Schönleitner, 2004). The elites, either in the executive or legislative branches, equally benefit from the local district financial wealth to protect their clientele and cronies. By manipulating the legislative process at subnational level, the elites in Camaçari influence government decision and policy that benefit them and their cronies. One of the major impacts of this process is the emergence a political master and local strongmen who become dominant formally in a local political scene.

The emergence of informal political elite in local politics is a common phenomenon in a new democratic country. In the Philippines, its people's power politics has been marred by the advent of informal elite who become interested in the political process (Sidel, 1999). These economic elite not only start to involve in the national political arena but have slowly infiltrated into subnational level. ${ }^{3}$ The aim is to capitalize their position in politics for economic interests. They have managed to capitalize local district's economic wealth by expanding their economic financial portfolios. This was done through land concession, law enforcement, appointment and promotion of public officers and government contract distribution. Sidel (1999: 156) points out that several provinces in Cavite, Cebu, and its surrounding area have been filled with industrial parks, golf courses, housing estates, tourist complexes-thanks to local economic bosses cum politicians who use their power to set the pace of development in their locality. They not only have the unlimited power to decide on the issue of area expansion, land acquisition to build roads, contract allocation, but also to deploy local police for specific tasks such as to counter demonstration by labor movement or to forcibly evacuate people from squatter areas.
The same situation also happens in Thailand. McVey's study in shes book entitled Money and power in provincial Thailand (2000), points out that economic bosses and local strongmen are a political reality for the country. They are known as chao pho (read: jao poh) or 'the protective father'. ${ }^{4}$ The presence of 'protective father' is not a new phenomenon for Thailand yet its position and role has strengthened ever since the 1973 democracy incident. They can be easily identified for their monopolistic traits and active involvements in every aspect of Thai's economic activities from mining, transportation, agriculture, printing, banking and others. The chao pho are also actively involved in contraband and illegal activities such as drug trafficking, smuggling and gambling (Arghiros, 2001).

Prior to 1973, the "protective fathers" were known for their involvement in providing protection for the local political elites. They were known for their ability to use force if necessary, and to garner some financial strength locally. But when the country moved to political transformations, "the protective fathers" acted as political and economic brokers" to the local politics. This was made possible since they had all the influential networking and followers. They could also contribute "votes" in local election to candidates who desperately needed to win. Through this link of support, cronies of "the protective father" managed to garner power and financial sources. Several chao pho even managed to stand as candidates for a parliamentary election and won. Narong Wongwan (a wellknown drug trafficker who has been barred to enter the United States) and Kamnan Po (a well known godfather from Chonburi province) are some of the examples (Arghiros, 2001).

It can be concluded that, based on the discussion above, democracy and democratization do not necessary produce positive impacts to the society. It can produce the opposite impact such as in Nigeria in 1983, Peru in 1992, and Sierra-Leone in 1997-just to name a few cases. ${ }^{5}$ Even if democracy runs smoothly in a particular country, it has to undergone various adaptation processes (political alignment or political 
adjusment) and in some instances produces political anomalies. Among these political anomalies is the emergence of economic bosses who become part of the political elites or strongmen in local politics. Their presence is correlated with and could affect political centralization as a result of polycentricism processes. This situation has been labeled as modus vivendi between the weak state and strong society. It contributes to local strongmen's political consolidation through increased role and influence in subnational politics.

Based on the above discussion, it can be argued that Indonesia's subnational political issues has to be studied not only from the structural aspect (i.e. autonomy and good governance, public relations and management and, other structural characters), but also has to be understood and perceived from the aspects of the agencies involved. The political transformational phenomenon that was briefly discussed above show the increasing role of local strongmen in the Indonesian post democratization process. Hence the analytical framework that will be used in this paper is based on local strongmen's impact (the negative side) (Migdal, 1988) on the dynamism of democratization process. According to Migdal (1988: 256), local strongmen and economic bosses are social control due to the fact that:

They have succeeded in having themselves or their family members placed in critical state posts to ensure allocation of resources according to their own rules, rather than the rules propounded in the official rhetoric, policy statements, and legislation generated in the capital city or those put forth by a strong implementor.

Furthermore, Migdal states that the argument is based on three inter-related points. First, local strongmen's strong growth is associated with closenetted society. They managed to get greater influences compared to that of other local leader or bureaucrats. Secondly, local strongmen also manage social control in the society through the strategy of survival. The logic is that these local strongmen create societal dependency on them, thus creating a legitimacy that only local strongmen are capable of solving societal problems. Local strongmen would become patron to the society- especially for the underprivileged. Third, local strongmen directly weaken state and local government's capacity to administer the province of the district.

This paper then discusses Migdal's theoretical framework in the context of Indonesia pre and postNew Order.

\section{RESULT AND ANALYSIS}

\section{LOCAL POLITICS PRIOR TO REFORMATION: THE ROOTS AND BEHAVIOR OF LOCAL STRONGMEN}

The dynamics of Indonesia's subnational politics have always changed through times. Prior to independence, the Nusantara's local politics was faced with gloomy period. It was because local politics was controlled and influenced by a strong traditional adat or custom. The majority of the population was not part or subject of development yet subject to series of taxes collected by repressive local officers. Hence, they were the object of political convenience of the local government. This situation made their economic conditions in a very dire need.

Continued uses of repressive method by the local officers finally led to the people's opposition and uprisings. It was led by local strongmen such as Ken Arok, Samin, Pitung and others who rose up against the central repressive power. These local strongmen represented some form of local people's civil opposition against the government. Local strongmen's role then led to positive image in the eyes of local population. They were seen as the protectors of local interests although some of these local strongmen did involve in illegal activities and part of underworld groups. Local strongmen's involvement and contribution to the society strengthened their position and polycentricism.

Indonesia's local politics became more dynamic after the proclamation of independence. This is due to the fact that more and more Indonesians are involved in the decision process of their own country by becoming part of local council and bureaucrats. 
The Dutch legacy of local political structure gave wider opportunities for the locals to be active or to be part of the country's political system. In the post- independent political system, members of the aristocrats were forced to compete with the local public to fill in posts in local government. In addition to that, there were also competitions based on ethnic line. Ethnicity is part and parcel of Indonesia's nation building problem even until today. There were political ethnic tension during the periods of Parliamentary Democracy (1950-1958) and Guided Democracy (1959-1965), especially outside the Java Island where military was directly involved in local politics. ${ }^{6}$ The local society was deprived from being active in politics. This also explains why Parliamentary Democracy era was replaced by the Soeharto's 1966 Guided Democracy. The Guided Democracy created mixed euphoria at the district level. It was seen as a new form of polycentricism or a new liberating politics that marked a new era of the Indonesian post-colonial period politics.

For more than 30 years, Indonesia was under the autocratic regime of Soeharto's New Order (19661998). During that period, local politics was controlled and centralized by Jakarta. As a result, executive bodies at district, sub district and provinces level were tied up under Jakarta's hegemony. Allocations for senior and higher posts at local level were decided by the Ministry of Internal Affairs (Kemdagri) in Jakarta. The ministry controlled the elite's interest at local level. In the election for the Riau governor in 1985, for instance, the Golkar Party directed all local parliamentary members to select Mejar Jeneral Imam Munandar (incumbent) as the governor. To ensure Munadar's winning the election, all senior party officers of Golkar were sent to Pekanbaru. As the election become nearer, representatives from the Tentara Nasional Indonesia (TNI)'s headquarters and Kemdagri were also sent to Pekanbaru. The military and the Golkar leaderships from the House of Local Representative (DPRD) met to discuss the scenario of the governor election. They decided that candidates would each receive three votes and the remaining votes would be given to the incumbent (Malley 1999:82). Although prior arrangements were made, the results showed the opposite. The September election gave Ismail Suko-a local politician-a clear winner by defeating the incumbent (who is a Javanese) only by two votes. President Soeharto nonetheless intervened and appointed Imam Munandar as the governor

This controlling mechanism was not only done by Jakarta to the local politics, but also to the military councils. To ensure easy control of the military council, ex-military men who have show their loyalty to the regime was awarded with special appointment either in the local legislative council (DPRD) or executive (governorship, district head or mayorship). This strategy excluded the appointment of senior military officers in the cabinet post or in the Parliament as special rewards for the military's loyalty.

Nonetheless, the rewards also led to undesirable consequences, especially at the district level. The military-cumlocal legislative officer tended to accumulate personal wealth. Power accumulation was easily done due to the military's long association with local development. As a result, they became the local mafias controlling all aspect of local activities and development. An editor to the Journal Indonesia from the Cornell University commented (1992: 98):

They have the opportunity to build powerful longterm local bases in the regions, first as representatives of the center, later as real-estate speculators, fixers, commission-agents, local monopolists, and racketeers. These long-term prospects, meaning retirement in the regions, are helped by local alliances, including marriage connections (themselves or their children), business partnerships with local elites, and personnel manipulations through former subordinates within the active military. As 'old hands,' such military men are in a strong position to inveigle or obstruct 'new broom' officers sent in from the center. Essentially, we are speaking of the formation of local mafias, which often have their eye on such 'civilian' political positions as bupati, provincial secretary, and even governor. 
The phenomenon did not start in 1980s but has been part of Indonesia's political dilemma since independence. For example, between 1967 and 1978, Wahab Sjahranie (a senior Colonel Officer from the ethnic of Banjar) capitalized Jakarta's weak control on local politics and District Military Command (KODAM)'s unassailability by using his political position to accumulate personal wealth and to consolidate his power base (Malley, 1999: 83). Through his governorship in East Kalimantan, the position for the KODAM's Commandant was replaced five times! The replacements show how KODAM was weakened by Wahab's manipulative strategies through his control over local bureaucrats and subsequently becoming a big local strongman. Not only was he managed to control local politics and bureaucrats, he used local police to protect and to strengthen his position by offering several loyal policemen a mayorship post.

Local strongmen did not only emerge from ex-military men. At the end of 1970s and in the early 1980s, for instance, a large inflow of development money created local aristocrats control over the appointments of regent, district secretary (Sekwilda), or members of DPRD by local aristocrats. These local aristocrats became local power house through their ownerships of hotel chains, plantation, manufacturing and cement industries. They used development monies as if it was theirs. Ichlasul Amal (1992: 179) wrote:

It was hard to find any bupati or high-ranking official in the governor's office who did not own profitable clove plantations or salt-water fishponds or both ... Officials owning large areas of productive land represented the continuation of a long established pattern in which aristocratic families owned land and invested some of the money they received from landowning in trade. But it also reflected the new economic climate of the New Order which enabled nobles who were also government officials to commercialize their landholdings.

In other words, local strongmen emerged as a result of New Order's development process. The central government's economic policy had given rise to economic opportunities and growth, industrialization, and social mobilization in Indonesia. ${ }^{7}$ In the 1980s and 1990s, for instance, the growth of local strongmen was phenomenal. They used social organization such as Pemuda Pancasila (that has close association with the regime in power) to garner support and power base. This type of local strongmen was also a political broker that used whatever means to provide support to the local bureaucrats either to end labor strike, student or pro-opposition demonstration. Ryter (2002) labels this type of local strongmen as preman or gangster.

The presence and involvement of this kind of semiofficial gangster in Pemuda Pancasila during the New Order period were actually needed. Local political elite often used them to stabilize local politics and more importantly to ensure Golkar's political winnings. They were in fact representing Golkar's voice in its political territories where local elite politicians received central government's economic distribution such as subsidy and contract for their own personal wealth-including retaining their power base. For instance, several Presidential Instructed Programs to finance the development of elementary schools, social health system, and public services either formally and informally benefited the local political elites (read: the local strongmen who cooperated closely with local elites) though various opportunities they themselves created. It can be considered as a broad daylight public misuse of funds or literally stealing money from the public

Based from the above discussion, it can be argued that Indonesia's local politics is very uniquely dynamic. Scholars may argue that Indonesia's New Order period was dictatorial. But it can only be true when we analyze it at the national level. The fact is that political reality at the local political level as this paper has shown so far is very much authoritarian. A question beg to be answered is why it has happened? It can be argued that national political virus has infected local politics. Yet what has happened to the 
local politics after the fall of the new order regime? The following section will discuss the issue raised in depth.

\section{REFORMING LOCAL POLITICAL ORDER: AN ILLUSIONAL CHANGE?}

The 1997 Financial Crisis and student movements led to the down fall of Soeharto regime and the end of Jakarta's centralization of power. The fall of New Order regime also marks the beginning of new polycentricism-that rejects concentration of power of the central government. Political reformation provides local district an autonomy to formulate, pass and implement laws without central government's intervention. The implementation of law also put an end to local elites' control on unsolicited money collection and the rejection of the role of local strongmen at district level. Political reformation has also weaken the central government's control at the local district politics since nobody could claim that he or she is representing Jakarta's interest. Hence, they have lost their political legitimacy. They no longer become a central government's power broker at district level. They are also no longer a single district authority. Polycentricism has replaced the logic of centralized politics.

The transformational changes from an "old politics" of centralization to a "new politics" or decentralization bring a new refreshing environment to Indonesia's local politics. At least the change flourished in the early years of reformation period. Nonetheless, scholars argue that Indonesia has been going back to the "old politics" whereby political brokers and local strongmen reappear at the subnational political level (Ryter, 2002; Hadiz, 2003; Agustino \& Yusoff, 2010b). This is due partly to the decentralization itself where central government no more involves in the local political process. These political brokers and local strongmen are actually the old faces who were unable to compete with the new order regime's local strongmen (Agustino \& Yusoff, 2010a). Yet, these "veteran" local strongmen continue to consolidate their position. They have managed to further expand their political base during the transitional period and at the same time able to manipulate the public's state of minds to further influence the society.

Democratization and decentralization process indeed provide more opportunities for local economic brokers and local strongmen to fill important political and bureaucratic posts at district councils and provincial legislative houses. For those who do not hold political or administrative posts, they make sure that important office bearers continue to depend on their assistance and support. Local policy formulations must benefit their businesses as well as their political domination in the local society. ${ }^{8}$

This, however, does not create a continuous dependency between local elite politics i.e. the office bearers and the economic boss/local strongmen. In some cases, the opposite has happened. In this kind of situation assistance provided by the local bearers to the economic bosses would benefit the earlier party the most. Research done by McCarthy (2002) in Southeast Aceh is very interesting. According to him (2002: 93-94):

At the apex of the network are four key business figures, predominantly from a particular Alas clan (marga). These figures dominated Southeast Aceh politics, and even the bupati was enmeshed in this network. Those who upset this group would be excluded from the webs of patron-client relations running Southeast Aceh.

Key figures there, allegedly including the bupati, are enmeshed in a social order that extends to forestry staff working for the National Park, police (Polres) and army personnel (Kodim), local government officials, the judiciary and local religious leaders (imam). Irrespective of the precise formal position within the state of those playing various roles, the links among businessmen, intermediaries, brokers and villagers lie outside the formal structure of the state.

Those kinds of interactions have emerged in many parts of Indonesia's post New Order politics. It can be seen further in Medan, one of the major towns in Sumatera island. Medan local parliament according to 
Vedi R. Hadiz (2003) has been dominated by a group of preman who compete among themselves. ${ }^{9}$ Some of them have even had special relations with ex senior army or police officers. In the early period of the Indonesian political reformation, the mayor of the city, Abdillah who was a charismatic economic boss, was elected to the post through vote buying and political intimidation. Having lived in a very competitive and cut throat political environment, one can explain why Abdillah administered the local bureaucratic system in a "punitive" way. Apart from local strongmen, there are also new actors in the local politics-the middle level businessmen who depend on government projects and social activists who are closely associated with non-governmental organizations (NGOs) such as the Indonesian University Students Group or Himpunan Mahasiswa Indonesia (HMI), the National Youth Committee of Indonesia or Komite Nasional Pemuda Indonesia (KNPI), the Indonesian University Student Movement or Gerakan Mahasiswa Nasional Indonesia (GMNI), and the Indonesia Christian University Students Movement or Gerakan Mahasiswa Kristen Indonesia (GMKI) (Hadiz, 2003: 125).

In addition to Aceh and Medan, there tend to be an increasing trend where economic bosses change their profession by becoming politicians in some districts. The networking of local strongmen has even expanded in many parts of Indonesia among others, Banten, East Java, and South Sulawesi. These places are not only under the control of powerful local economic bosses, but also under the influences of local aristocrat, respected religious figures and indigenous adat leaders. The last three leaders have the charismatic charms and would manipulate ethnic, religious and adat sentiments to stir up local societal emotion. This can be seen in the Ambon's ChristianMuslim conflicts in Maluku (van Klinken 2001). Power rivalry between the Ternate and Tidore Sultanates also led to local political conflicts in North Maluku. The royal feuds also triggered religious conflict in the area. (Ibid.). In Central Kalimantan, ethnic conflict has had slowly evolved into strings of political enmity in the election process and Pilkada (Taufiq Tanasaldy 2007). The increasing influences of local strongmen also include political enmity among local elites in the drafting of new autonomy law for the district through redistricting policy (Aragon, 2007).

In other context, local politics have to be understood as a competition ground for the three powerful political giants: (i) bureaucrats with aristocratic background, (ii) bureaucrats who initially came from an average social background, and (iii) the local strongmen. The competition among them may force them to cooperate, but more so to kill each other's political base. We can see their rivalry in the redistricting process (redrawing the constituencies at provincial, regent or city level). When one group of bureaucrats (for instance those who are coming from an average social background) failed to implement the redistricting process, the other group of bureaucrats (with aristocratic background) would take the opportunity to go against the regime in power. Hence, the bureaucrats with aristocratic background used the opportunity to redraw the constituency that would benefit them. The rivalry was further heightened when local strongmen intervened. Their involvement was mostly to get major slices of the cake as a result of redistricting process. They hope to gain more business opportunities when the constituencies are redrawn. ${ }^{1010}$ The formation of new district autonomy created many advantageous. Among others, it has opened up various important bureaucratic positions or posts such as for developments and public relations to be filled.

Local businessmen also benefited with the redistricting policy. Financial distribution became less bureaucratic. Business entity could receive their money more quickly than before once the project is completed thus contributed to increased income. Local political elites also benefited from the decentralization process. Chances to sit in the district important posts such as head of district or becoming head and members of the province's local parliament or DPRD became wider. For bureaucratic elites, their opportu- 
nity to climb up the ladder has become easier. Outside Java area, bureaucrats with aristocratic background have the upper hand. This is because they are able to a number of new autonomic provinces, regents and cities according to their own wimps and fancies. The number of new regents are in fact multiple. Local aristocrats with higher educational background are easily inducted into local offices or military services through lobbying with local Golkar party or with those powerful figures in Jakarta. In some cases a delegation would be sent to Jakarta by the local DPRD to convince the Parliamentary Commissioner II of DPR to create more autonomy districts. In this case, local strongmen cum economic bosses are needed to provide financial support for the visit of DPR members to their areas. The bargaining between two parties may infer that local strongmen would gain benefits from the redistricting processes, especially when a new district is created.

The discussion so far has shown that local politics in Indonesia is a combination of a clash of interest between that of local strongmen' (including the economic bosses) and bureaucrats. The two groups strive to maintain their power in their district. Each of them would ensure that they continue to control the sources of the district's economic wealth. It is not surprising when Amrih Widodo (2003: 190), argues that the dark side of decentralisation during the Reformation order period is:

... a new modus vivendi based on negotiation and dealmaking appears to be evolving between the bureaucracy and the legislature. The system serves as an avenue for political players to maximise their access to resources and enhance their political standing. Each tries to outdo the others, because they all realize that victory in the fight for strategic positions depends on being able to mobilise financial resources and build a popular support base.

Yet the local political transformation in Indonesia is not as severe when we compare to what has happened in Thailand. In Thailand local strongmen's roles are more centralized on one chao pho and rigidly divided into several groups. The role of local strongmen in Indonesia, however, is fluid, nonmonolithic and indecisive. The major focus of local strongmen in Indonesia is to build local political dynasty by centralizing their power base. One case is now happening in Banten. Leo Agustino \& Mohammad Agus Yusoff (2010b) argue that the evolution of local strongmen in Banten has entered into the formation of a local political dynasty. ${ }^{11}$ Currently, the Banten political dynasty created by Tubagus Chasan Sochib manages to place his family members and cronies in important local government posts and businesses (formally and informally).

One conclusion can then be made-Indonesian local politics is still in an evolving stage. The direction of the development is very much influenced by the local strongmen's political consolidation (this has been shown by several examples discussed in this paper). If it is argued that the creation of district autonomy has created more good practices, the findings and assumptions of this paper may not be relevant. One may argue that some districts such as Yogyakarta do not experience local strongmen's political control. But one has to remember that although local strongmen are not powerful in Banten, for instance, their tendency to become political investors in Pilkada and subsequently influence the decentralization process at the subnational level is much greater. Political investors, compared to that of financial investors, would continue to create "benefits and opportunities" to ensure that those in power would continue to support them. If this trend continues, Indonesia's subnational politics would have its gloomy faces if attempts are not made to change it. This led to the perceived changes to remain an illusion.

\section{CONCLUSION}

Indonesia's subnational politics has undergone dramatic tribulation period in recent years. At one time, central political elites intervened directly in the local or district affairs especially during the early years of the Indonesia's post-independence period and also during the New Order period. Yet in the political 
reformation period, local politics have been able to enjoy more freedom and able to chart its own political directions.

Two major lessons can be learned from Indonesia's local politics dynamics. The first is that there have been attempts by the central government to continuously control the local political landscape. Second is, based on the discussion of this paper, the emergence of "strongmen" as the major force in influencing local politics. The local strongman emerges due to strategies used by the New Order regime to monitor and operate its enforcement mechanism at subnational political levels, and more importantly as mechanism of resistance to the decentralization processes. Yet, Indonesia's subnational politics in the pre and post 1998 periods remained to be controlled by local strongmen that led to autocratic nature of local politics.

The role of strongmen in the district autonomy either through Pilkada or Redistricting has had shaped local political scene. This is because prior to the downfall of the New Order government, local strongmen were controlled or even suppressed by the Soeharto regime that jealously guarded its power base through coercive apparatus at the district level. This strict control is partly due to the regime's restricting objective of Jakarta's centralization approaches. But in the reformed era, strongmen's role in the local political and economic manipulation is difficult to contain. Hence, the transformation from "old politics" (centralization of power) to "new politics" (decentralization) fails to benefit the people at the subnational level. It is only those who have the power (local strongmen) and money (powerful businessmen) who continue to have the advantage even under the current democratic era of Indonesia. The paper concludes that "old" political actors who benefit the most during the New Order period have been able to reassert themselves under the new political environment and continue to become powerful than ever. Political reform that is expected to bring about total changes to the Indonesian politics hence remains static.

\section{ENDNOTES}

1 This paper was presented in the Fifth International Conference on Global Studies, Moscow, Russia, 20-22 June 20-22. Paper was modified for this journal.

2 Civil society is considered an agent for political transformational change. This is because civil society is not only defined as an informal social cohesion group that has the ability to garner social support and solidarity and promote universal norms and values accepted by all strata of life (c.f. Cohen \& Arato 1992), but more importantly, it could create inner social strength that could balance government's indifferent attitudes on humanity and injustice (Gellner 1994:5). In spite of that, civil society is believed to have the ability to defend the interests of the public and to prevent government's manipulative social strategies. At the same time Chandhoke (1995:8-13) adds that civil society is an avenue where "... at which society enter into relationship with the state." From this perspective, the society manages to interact and to raise critical issues rationally with the government. The interactions would dampen the regime's intention to accumulate more power and to becoming autocratic.

3 Boss or the Economic Elites in the Philippines derives from the historical linkages between family dynasty of 'old landlord' (oligarchs) with its networks and patron-client relationship between them. Some of these old family oligarchies (economic boss) are also the major players in the Philippines politics. Among them are the family of Lacson and Montelibanos from the Negros Province, Osmeoas and Duranos from Cebu, and Joson and Diazezs of Nueva Ecija. Cory Aquino and Gloria Macapagal Arroyo are also part of this political oligarchic system. The boss, coming from the family 'old oligarchs' and involve in politics, was initially has a strong local strongmen lineage. They were the economic and political broker and hold monopolistic position in their local society. When these bosses have enough 'capital investment', they would then run in the parliamentary elections and become political leaders in their area. It is seldom that they would not be selected. But the way they run their local district is just like a mafia style. They would consolidate more power and wipe out all political opponents through manipulative voting systems or in some extreme form using force to eliminate their opponents. For further discussion on this, see Sidel (1999).

4 According to McVey (2000), their presence can be categorized into three levels: First, pre-1960. There are two conditions of which led to the emergence of chao pho, (i) strong patriarchal cultural in the society; and (ii) an ineffective control and weak government in the internal district areas. In this kind of situation, the role of godfather is permissible as the main player for local politics (middle distance between capital and countryside). Second, between 1960s and 1973, the anticommunist military regime under Jeneral Sarit Thanarat (1958-1963) and Jeneral Thanom Kittikachorn (19631973), had included countryside areas as part of extensive infrastructure development plan. Subsequently, the godfather used their influences to be part of the project development, and some of them became the head of villagers, whom the task was among others to increase local tax revenues. Third, a more democratic regime was introduced through local electoral process after the fall of military regime. The process allows them to get 
involve in national politics directly and independently.

5 In Nigeria for instance, democratization process took longer period (from 1974 until early period of 1980s). The protracted democratic process ignited a coup by General Abacha who was very impatient with the slow process. He subsequently ruled the country with iron-fist. In Peru, President Alberto Fujimori organized a self-coup on 5 April 1992. He justified his action by arguing that the country was in emergency due to acute economic problems and ineffective leadership. He dissolved the parliament and ruled the country single handedly. The same situation also occurred during the failed transitional process of Sierra Leone's democracy in 1997. Democracy failed to stabilize the country due to vested interests among political elites. The country was drawn into a series of civil war. Please refer to Kay (1996), Emelifeonwu (1999), and Keen (2005) for further information on the issues.

6 In spite of that, there are many small groups that have colored the ethnic works in Indonesia. For instance Burhan Magenda's works (1989) show that there was continuity of power among the aristocrats outside Java Island (East Kalimantan, Nusa Tenggara Barat, and South Sulawesi) after the proclamation of independence. The study also argues that in the 1950s the Indonesian Civil Service was still managed by members of Javanese aristocrat of whom maintaining their ally with that of from outside the Java Island. Their alliance was based on common in interests i.e. to limit the expansion of leftist idea and Islamism that wanted to launch a new political force. This common interest also benefited the bureaucrats who needed the aristocrat's influences in managing ethnic conflicts. At the same the aristocrat also needed bureaucrat's support to deal with local's opposition against them.

7 In this context, Orde Baru or New Order regime attempted to present a multiple positive impacts of capitalisme. However, rentseeking activities, crony capitalism, and patrimonial hierarchy practices continued to reinforce itself and created a web of networks. This then contributed to a situation where one could not get away from the web of networks once he/she was in. It has then been resulted with at least $30 \%$ of foreign investment went directly to political elite's coffin. The practices also allowed cronies to get their own shares at the district level.

8 Harriss-White (1992) names this activity as "informal economy", where strong local people benefits the most through their personal ties with the government. These strong local men continue to influence local, district and parliamentary leadership through: "... the use of trusted family labour; bilateral and multilateral contracts, especially repeated and interlocked contracts; individual and collective reputation; collective institutions; an inconsistent normative pluralism; and private protection forces" (Harriss-White 1999:5). Furthermore, she explains:

Some elements of the shadow state are played simultaneously by real state players, e.g. corrupt lines of tribute, patronage/ clientelage. Other shadow state livelihoods are a form of self employment, though they depend on state employees, politicians and other interested social forces for their incomes e.g. private armies enforcing black or corrupt contracts, intermediaries, technical fixers, gatekeepers, adjudicators of disputes, confidants, consultants, and chore performers.

Hence the real state with its shadow is bigger than the formal state and has a vested interest in the perpetuation of a stricken and porous state. The shadow state spills spatially into the lanes surrounding offices and into the private (some argue the 'female') domestic space of an official's residence. This must be the most vivid image of the blurred boundaries between state and society (Harriss-White 1999:15).

9 Three names were identified as notable non-military trained youth leaders in Medan: Bangkit Sitepu, head of division for Pemuda Pancasila (PP) Medan, a social civilian organization during the new order era. The organization received supports from the government and had an affiliation with Golkar Party; Moses Tambunan, leader of Ikatan Pemuda Karya (IPK) — Golkar Party's youth wing; and Martius Latuperisa member of Partai Keadilan dan Persatuan (PKP) under the leadership of Jeneral (Retired) Edi Sudrajat, who was also the major prime mover for the Forum Komunikasi Purnawiaran Putera-Putri ABRI (FKPPI) Medan. For further discussion please see Ryter (2002) and Vedi R. Hadiz (2003).

10 The formation of new district autonomy created many advantageous. Among others, it has opened up various important bureaucratic positions or posts such as for developments and public relations to be filled. Local businessmen also benefited with the redistricting policy. Financial distribution became less bureaucratic. Business entity could receive their money more quickly than before once the project is completed thus contributed to increased income. Local political elites also benefited from the decentralization process. Chances to sit in the district important posts such as head of district or becoming head and members of the province's local parliament or DPRD became wider. For bureaucratic elites, their opportunity to climb up the ladder has become easier.

11 According to Leo Agustino \& Mohammad Agus Yusoff (2010), the evolution starts when the autonomy law was implemented through the formation of Provinsi Banten through the redistricting mechanism. Since thenu, Tubagus (Tb.) Chasan Sochib—a 'tameng' and local strongmen during New Order-plays a dominant role in the administration of Banten. In the early period of the formation of Banten as a separate province, he appointed his own son (Ratu Atut Chosiyah) as deputy governor instead of his political ally, Djoko Munandar (from the Partai Persatuan pembangunan). Ratut Atut was then appointed as governor of Banten until 2011.

\section{BIBLIOGRAPHY}

Agustino, Leo \& Mohammad Agus Yusoff. 2009. Pilkada dan pemekaran daerah dalam demokrasi lokal di Indonesia: local strongmens dan roving bandits. Paper Presented at the Seminar Serumpun IV Organized by Pusat Pengajian Bahasa, Kesusteraan dan Kebudayaan Melayu, Fakulti Sains Sosial dan Kemanusiaan, Universiti Kebangsaan Malaysia (UKM) in association with Fakultas IImu Budaya, Universitas Hasanuddin (Unhas). Bangi, Selangor, Malaysia, 4-5 July.

Agustino, Leo \& Mohammad Agus Yusoff. 2010. Dinasti politik di Banten pasca Orde Baru: sebuah amatan singkat. Jurnal Administrasi Negara 1(1): 79-97.

Amal, Ichlasul. 1992. Regional and central government in Indonesia politics: West Sumatra and South Sulawesi 1949-1979. Yogyakarta: Gadjah Mada University Press.

Aragon, L.V. 2007. Persaingan elit di Sulawesi tengah. In HenkS. 
Nordholt dan Gerry van Klinken (ed), Politik lokal di Indonesia. Translation. Jakarta: Yayasan Obor Indonesia dan KITLV Jakarta.

Arghiros, D. 2001. Democracy, development and decentralization in provincial Thailand. Surrey: Curzon.

Chandhoke, N. 1995. State and Civil Society: Exploration in Political Theory. London: Sage Publication.

Cohen, J-L., \& Arato, A. 1992. Civil society and political theory. Cambridge: Massachussetts Institute of Technology Press.

Diamond, L. 1994. Rethinking civil society: toward democratic consolidation. Journal of Democracy 5(3): 151-159.

Emelifeonwu, D.C. 1999. Anatomy of a failed democratic transition: the case of Nigeria. PhD Dissertation. McGill University.

Escobar, A. \& Alvarez, S.E. (ed). 1992. The making of social movements in Latin America: identity, strategy, and democracy. Boulder: Westview.

Gellner, E. 1994. Conditions of liberty: civil society and its rivals. London: Hamish Hamilton.

Hadiz, Vedi R. 2003. Power and politics in North Sumatra: the uncompleted reformasi. In Edward Aspinall \& Greg Fealy (ed), Local power and politics in Indonesia: decentralisation \& democratisation. Singapore: ISEAS.

Hansen, T.B. 1999. The saffron wave: democracy and Hindu nationalism in modern India. Princeton: Princeton University Press.

Harriss-White, B. 1999. How India works: the character of the local economy. Cambridge: Cambridge University Press.

Kay, B.H. 1996. Violent democratization and the feeble state: political violence, breakdown and recomposition in Peru, 1980-1995. PhD Dissertation. University of North Carolina.

Keen, D. 2005. Conflict and collusion in Sierra Leone. Oxford: James Currey Publishing.

Laclau, E. \& Mouffe, C. 1985. Hegemony and socialist strategy: towards a radical democratic politics. London: Verson.

Magenda, Burhan. 1989. The Surviving Aristocracy in Indonesia: Politics in Three Province of the Outer Islands. PhD Dissertation. Cornell University.

Malley, M. 1999. Regions: centralization and resistance. In Donald K. Emmerson (ed), Indonesia beyond Suharto: polity, economy, society, transition. New York: M.E. Sharpe.

McCarthy, J.F. 2002. Power and interest on Sumatera's rainforest frontier: clientiest coalitions, illegal logging and conservation in the Alas Valley. Journal of Southeast Asian Studies 31(1): 83-102.

McVey, R. (ed). 2000. Money and power in provincial Thailand. Copenhagen: Nordic Institute of Asian Studies (NIAS).

Migdal, J.S. 1988. Strong societies and weak state: state-society relations and state capabilities in the third world. Princeton: Prnceton University Press.

Mohan, G. \& Stokke, K. 2000. Participatory development and empowerment: the dangers of localism. Third World Quarterly 21(2): 247-268.

Robison, R., \& Vedi R. Hadiz. 2004. Reorganising power in Indonesia: the politics of oligarchy in an age of markets. London: RoutledgeCurzon.

Ryter, L. 2002. Youth, gangs, and the state in Indonesia. PhD Dissertation. University of Washington.

Scönleitner, G. 2004. Can public deliberation democratise state action?: municipal health council and local democracy in Brazil. In John
Harriss, Kristian Stokke, \& Olle Tornquist (ed), Politicing democracy: the local politics of democratisation. New York: Palgrave Macmillan.

Sidel, J. 1999. Capital, coercion, and crime: bossism in the Philippines. Stanford: Stanford University Press.

Tasanaldy, Taufiq. 2007. Politik identiti di Kalimantan Barat. In Henk S. Nordholt \& Gerry van Klinken (ed), Politik lokal di Indonesia. Translation. Jakarta: Yayasan Obor Indonesia dan KITLV-Jakarta.

The Editors. 1992. Current Data on the Indonesian Military Elite. Indonesia 53(April): 93-136.

van Klinken, G. 2001. The Maluku wars of 1999: bringing society back in. Indonesia 71(April): 1-26.

van Klinken, G. 2007. Communal violence and democratisation in Indonesia: small town wars. London: Routledge.

Varshney, A. 2002. Ethnic conflict and civic life. New Haven: Yale University Press.

Wellhoer, E.S., 2005. Democracy, facism and civil society. In S. Roßteutscher (ed), Democracy and the role of associations: political, organizational and social contexs. London: Routledge.

Widodo, Amrih. 2003. Changing the cultural landscape of politics in post-authoritarian Indonesia: the view from Blora, Central Java. In Edward Aspinall and Greg Fealy (ed), Local power and politics in Indonesia: decentralisation \& democratisation. Singapore: Institute of Southeast Asian Studie. 